\title{
Comparison of the clinical and radiological outcomes of open reduction via medial and anterior approach in devleopmental dysplasia of the hip
}

\author{
Gelişimsel kalça displazisinde medial ve anterior yaklaşımla açık redüksiyonun \\ klinik ve radyolojik sonuçlarının karşılaştırılması
}

\author{
Hüseyin Yorgancıgil, MD., ${ }^{1}$ Ahmet Aslan, MD. ${ }^{2}$ \\ 1'Department of Orthopedics and Traumatology, Medical Faculty of Süleyman Demirel University, Isparta, Turkey \\ ${ }^{2}$ Department of Orthopedics and Traumatology, Afyonkarahisar State Hospital, Afyonkarahisar, Turkey
}

\begin{abstract}
Objectives: This study aims to investigate the effects of surgical approach on the clinical and radiological outcomes, the incidence of avascular necrosis (AVN), and the need for revision surgery in children undergoing open reduction via medial or anterior approach for developmental dysplasia of the hip (DDH).
\end{abstract}

Patients and methods: Forty-three hips of 36 patients (9 males, 27 females; mean age 13.8 month; range 6 to 18 months) treated for DDH, followed-up regularly for at least four years between January 1997 and December 2010, and who were aged five or above in the final control were included in this retrospective study. Patients were divided into two groups according to surgical approaches. Group 1 consisted of 21 hips of 19 patients who underwent open reduction through medial approach. Group 2 consisted of 22 hips of 17 patients who underwent open reduction through anterior approach. Groups were compared in terms of clinical and radiological outcomes as well as the incidence of AVN and the need for revision surgery.

Results: There was no statistically significant difference between the groups with respect to clinical and radiological outcomes ( $\mathrm{p}=0.407$ and $\mathrm{p}=0.661$, respectively). Similarly, there was no statistically significant difference between the groups in terms of AVN incidence and need for revision surgery $(p=0.993$ and $\mathrm{p}=0.170$, respectively). On the other hand, acetabular index improved significantly in both groups at follow-up.

Conclusion: This study showed that open reduction via medial or anterior approach in DDH has similar clinical and radiological results, significant improvement was achieved in the acetabular index with both approaches, and no significant difference was present in the incidence of AVN and the need for revision surgery between the groups.

Keywords: Anterior open reduction; avascular necrosis; developmental dysplasia of hip; medial open reduction; revision surgery.

\section{ÖZ}

Amaç: Bu çalışmada gelişimsel kalça displazisi (GKD) nedeniyle medial veya anterior yaklaşımla açık redüksiyon uygulanan çocuklarda cerrahi yaklaşımın klinik ve radyolojik sonuçlar, avasküler nekroz (AVN) insidansı ve revizyon cerrahisi gerekliliği üzerindeki etkileri araştırıld1.

Hastalar ve yöntemler: Ocak 1997 - Aralık 2010 tarihleri arasında GKD tedavisi yapılan, en az dört yıl düzenli takip edilen ve son kontrolde beş yaş ve üzerinde olan 36 hastanın (9 erkek, 27 kız; ort. yaş 13.8 ay; dağılım 6-18 ay) 43 kalçası bu retrospektif çalışmaya dahil edildi. Hastalar cerrahi yaklaşıma göre iki gruba ayrıldı. Grup 1, medial yaklaşımla açık redüksiyon uygulanan 19 hastanın 21 kalçasından oluştu. Grup 2, anterior yaklaşımla açık redüksiyon uygulanan 17 hastanın 22 kalçasından oluştu. Gruplar klinik ve radyolojik sonuçlar ile AVN insidansı ve revizyon cerrahisi gerekliliğ bakımından karşılaştırıldı.

Bulgular: Klinik ve radyolojik sonuçlar bakımından gruplar arasında istatistiksel olarak anlamlı farklılık yoktu (sırasıyla, $\mathrm{p}=0.407$ ve $\mathrm{p}=0.661$ ). Benzer şekilde, AVN insidansı ve revizyon cerrahisi gerekliliği bakımından da gruplar arasında istatistiksel olarak anlamlı farklılık yoktu (sırasıyla, $\mathrm{p}=0.993$ ve $\mathrm{p}=0.170$ ). Diğer yandan, takipte her iki grubun asetabüler indeksi anlamlı olarak düzelmişti.

Sonuç: Bu çalışma, GKD’de medial veya anterior yaklaşım ile açık redüksiyonun klinik ve radyolojik sonuçlarının benzer olduğunu, her iki yaklaşımla da asetabüler indekste anlamlı düzelme elde edildiğini ve AVN insidansı ve revizyon cerrahisi gerekliliği bakımından gruplar arasında anlamlı farklılık olmadı̆̆ını göstermiştir.

Anahtar sözcükler: Anterior açık redüksiyon; avasküler nekroz, gelişimsel kalça displazisi; medial açık redüksiyon; revizyon cerrahisi.

- Received: January 27, 2016 Accepted: May 03, 2016

- Correspondence: Ahmet Aslan, MD. Afyonkarahisar Devlet Hastanesi Ortopedi ve Travmatoloji Kliniği, 03400 Afyonkarahisar, Turkey. Tel: +90 505 - 6462411 Fax: +90 272 - 2137936 e-mail: draaslan@hotmail.com 
The purpose of treatment for developmental dysplasia of the hip (DDH) is to provide and maintain early concentric reduction without harming circulation in the femoral head. Algorithms which contain various treatment methods according to age and findings have been proposed. ${ }^{[1-4]}$ The use of conservative treatment methods such as a Pavlik harness frequently take place in the first six months. Open reduction is usually required if closed reduction cannot be achieved in children older than six months. This decision is made based on age, clinical and radiological findings. ${ }^{[2,5,6]}$ However, it has been reported that a stable hip cannot be achieved by way of closed reduction in 12-43\% of the patients. ${ }^{[7]}$ Open reduction is most commonly performed using the medial open reduction (MOR) or anterior open reduction (AOR) approach. ${ }^{[1,6,8,9]}$

The medial approach is a simple, safe and cosmetically pleasing method which does not require blood transfusion and provides direct access to the medial structures with minimal dissection. However, it has some disadvantages. These disadvantages include a limited view which does not allow capsule plication and the risk of disruption of the medial circumflex artery. ${ }^{[6,10-12]}$ Open reduction with an anterior approach is used more frequently and provides a larger angle of view. It enables both capsular plication and pelvic osteotomy with the same incision. Vascular structures around the femur neck and shaft are preserved. Its disadvantages include a lengthier operation, more dissection of the soft tissues, increased blood loss and it is more difficult to reach the structures which hinder reduction in medial approach. ${ }^{[6,8,12-14]}$

Successful results have been reported in various studies using both approaches. ${ }^{[9,13,15-18]}$ Avascular necrosis $(\mathrm{AVN})$ and the need for revision surgery are reported at various rates. ${ }^{[2,11,12]}$ Limited number of studies are available comparing the results of open reduction with anterior or medial approach. ${ }^{[11,12]}$ However comparative evidence about the preference for each approach in treatment of DDH in patients between 6-18 months and the benefits of each is not sufficient.

In this study, we investigated the clinical and radiologic results of surgical treatment with MOR or AOR in children with DDH between 6-18 months and the frequency with which follow-up surgery was required.

\section{PATIENTS AND METHODS}

Surgical treatment with MOR and AOR was performed in the patients who were diagnosed with typical DDH with radio-diagnostic and clinical findings in the Orthopaedic and Traumatology
Clinics of Süleyman Demirel University Faculty of Medicine, Kastamonu and Afyonkarahisar State Hospitals where the authors worked during a 14 year period between January 1997 and December 2010. (i) Potential patients were excluded due to known neuro-muscular disease, (ii) hips in which the reduction was achieved with gentle manipulation under general anesthesia and not dislocated in the safe range, (iii) cases in which the reduction could be achieved with only iliopsoas tenotomy using a medial approach, ${ }^{[19]}(i v)$ cases which required further surgical intervention such as acetabular osteotomy in the course of anterior open reduction depending on the Zadeh et al. ${ }^{[20]}$ stability test.

Forty-nine hips of 41 patients who had regularly attended followed up appointments for at least four years and who were five-year-old or above at the time of the last visit were included in the study. Of them, five patients (6 hips) were excluded from the study as the last control data could not be obtained. Finally, results of 43 hips of 36 patients (9 males, 27 females; mean age 13.8 month; range 6 to 18 months) were evaluated. From Süleyman Demirel University Faculty of Medicine Clinical Research Ethics Committee approval was obtained. Parents were informed that medical records could be used for scientific purposes only and informed consent was obtained during the last visit. The study was conducted in accordance with the criteria of Helsinki Declaration.

The selection of an open reduction surgical approach was determined according to patients' age, clinical and radiologic findings and most importantly, the surgeon's experience and preference. The patients were retrospectively divided into two groups in order to compare the clinical and radiologic results of the treatment method. Group 1 was composed of 21 hips of 19 patients who underwent MOR. This approach was performed according to the algorithm of Biçimoğlu et al. ${ }^{[19]}$ A pelvipedal cast was applied in the human position. Group 2 was composed of 22 hips of 17 patients who underwent AOR. This approach was performed using a modified SmithPetersen (bikini) incision. ${ }^{[10]}$ After the operation, a pelvipedal cast was applied in the near-human position.

\section{Follow-up and evaluation}

The casts were made including the knee of the limb which was not operated on in neutral position in unilateral cases. The knees were in mild (15-20 degrees of) flexion and ankles were in neutral position in bilateral cases. The patients were kept in pelvipedal cast for 12 weeks in MOR group, 

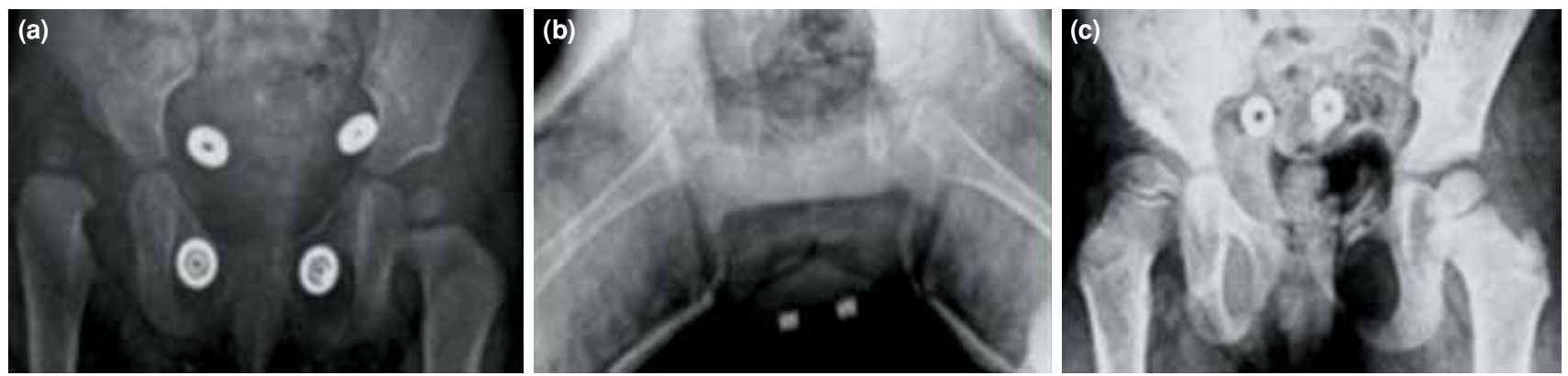

Figure 1. Patient's (a) preoperative, (b) postoperative and (c) follow-up radiograph in group medial open reduction.

and six weeks in AOR group. Then, an abduction orthosis was used for approximately three months (full-time for the first six weeks and only at night for the remainder). X-rays were obtained preoperatively (Figure 1a and Figure 2a), postoperatively (Figure $1 b$ and Figure $2 b$; in cast), during orthosis use and thereafter (Figure 1c and Figure 2c). The patients were followed up clinically and radiologically every three months during the first year, every six months during the second year and once a year thereafter. Radiologic and clinical findings before, after the operation and during follow-up were recorded. The patients were classified as successful (excellent and good outcomes) and unsuccessful (fair and poor outcomes) according to modified Mac-Kay criteria ${ }^{[21]}$ at the last visit. Radiologically successful outcomes were evaluated according to the classification of Ömeroğlu et al. ${ }^{[22]}$ The other radiologic measurements such as acetabular index (AI) and center-edge (CE) angle were done according to original definitions. ${ }^{[23,24]}$ The AVN diagnosis was made regarding the criteria of Salter et al., ${ }^{[25]} \mathrm{AVN}$ classification was based on the criteria of Kalamchi-McEwen. ${ }^{[25,26]}$ Preoperative typing was classified according to Tonnis staging. ${ }^{[27]}$

\section{Statistical analysis}

Statistical analysis were performed using IBM SPSS version 21.0 (IBM Corporation, Armonk, NY, USA). Normality distribution of the data was done using the Kolmogorov-Smirnov test. The differences between groups with regard to clinical, radiologic outcomes and revision, AVN were analyzed with chisquare test and Fisher's exact test. Mann-Whitney U test was used for comparison of angle measurements between groups. A $p$ level of $<0.05$ was accepted as statistically significant.

\section{RESULTS}

The patients were followed up for 48-168 months. There was not a statistically significant difference between groups with regard to age at treatment and duration of follow-up ( $\mathrm{p}=0.072$ and $\mathrm{p}=0.903$, respectively) (Table I). There was also not a statistically significant difference between groups with regard to gender and side ( $\mathrm{p}=0.420$ and 0.864 , respectively) (Table II). When groups were compared with regard to preoperative Tönnis staging, there were higher dislocations in AOR group compared to MOR group $(\mathrm{p}=0.05)$ (Table II). This condition could have affected our results. On the other hand, AI significantly improved after the operation in both groups (Table I).

During clinical assessment, there was not a statistically significant difference between MOR and AOR groups with regard to successful outcomes ( $80.9 \%$ and $81.8 \%$, respectively) ( $\mathrm{p}=0.407$ ) (Table II). Radiologic assessment results were not different between the MOR group (76.2\%) and AOR group $(77.3 \%)(p=0,661)$ (Table II). There was not a statistically significant difference between groups with regard to
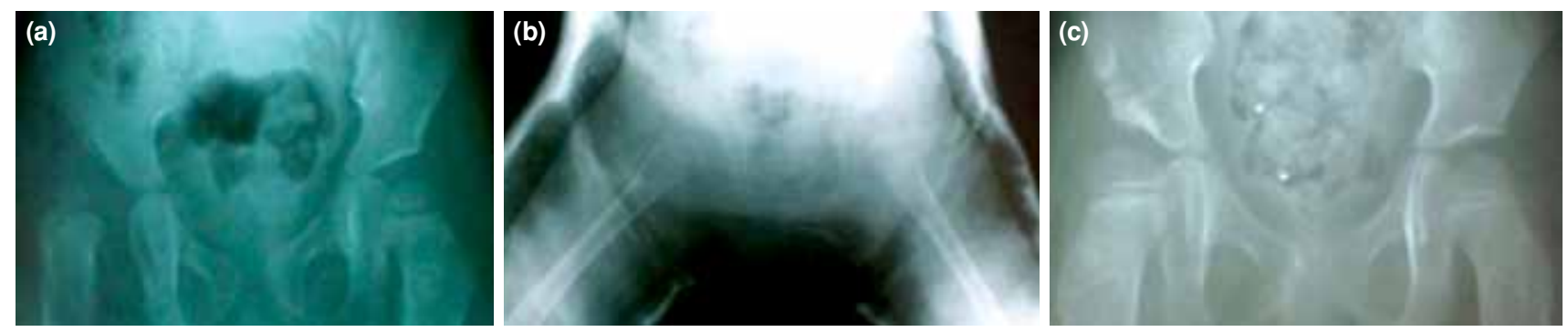

Figure 2. Patient's (a) preoperative, (b) postoperative and (c) follow-up radiograph in group anterior open reduction. 
TABLE I

Comparison of demographic data and the angular measurements between the groups

\begin{tabular}{|c|c|c|c|c|c|}
\hline \multirow[b]{2}{*}{ Parameters } & \multicolumn{2}{|c|}{ Group MOR $(n=21)$} & \multicolumn{2}{|c|}{ Group AOR $(\mathrm{n}=22)$} & \multirow[b]{2}{*}{$p^{*}$} \\
\hline & Min.-Max. & Mean $\pm S D$ & Min.-Max. & Mean $\pm S D$ & \\
\hline Age (months) & $6-17$ & $13.00 \pm 2.87$ & $11-18$ & $14.55 \pm 2.60$ & 0.072 \\
\hline Follow-up (months) & $48-105$ & $75.24 \pm 19.56$ & $50-168$ & $84.00 \pm 29.46$ & 0.903 \\
\hline Acetabular angle $\left({ }^{\circ}\right)$ & $45-52$ & $48.62 \pm 2.31$ & $47-53$ & $49.50 \pm 1.90$ & 0.193 \\
\hline Center-edge angle $\left({ }^{\circ}\right)$ & $11-26$ & $17.19 \pm 4.40$ & $11-25$ & $17.78 \pm 3.99$ & 0.493 \\
\hline Acetabular index (Preoperative) & $27-41$ & $33.91 \pm 5.38$ & $31-43$ & $37.55 \pm 3.99$ & 0.608 \\
\hline Acetabular index (Postoperative) & $15-28$ & $21.86 \pm 3.93$ & $15-27$ & $21.23 \pm 3.70$ & 0.226 \\
\hline Acetabular index (improvement) & $9-21$ & $12.05 \pm 5.27$ & $10-25$ & $16.32 \pm 4.83$ & 0.019 \\
\hline
\end{tabular}

SD: Standard deviation; * Mann-Witney U test

need for revision surgery and AVN development ( $\mathrm{p}=0.170$ and $\mathrm{p}=0.933$, respectively) (Table II).

While there was the history of unsuccessful Pavlik harness treatment in one patient in MOR group, there was also the history of an unsuccessful closed reduction in one patient in AOR group. Dermatitis was seen in one case, superficial wound infection was seen in two cases and they were successfully treated. Demographic, clinical and radiologic outcomes of the patients in both groups are summarized in Table I and Table II.

\section{DISCUSSION}

The main purpose of DDH treatment in all stages is to provide reduction, to correct joint instability and achieve the normal developmental process of the hip. Secondary degenerative arthritis has been seen in young patients who were treated later than and less sufficiently than recommended, or who were neglected may be reduced with proper treatment. ${ }^{[28-31]}$ Conservative methods and closed reduction are attempted first. However unstable closed reduction usually results in unsatisfactory function. ${ }^{[1,7,32]}$ Open reduction between 6-18 months is usually mandatory. Open reduction is most commonly performed with the MOR or AOR approach and both approaches have the above mentioned advantages and disadvantages. ${ }^{[2,9-11]}$ However some modifications of MOR like anteromedial and posteromedial have been defined. ${ }^{[10,15,16,33]}$ Anterior open reduction, another open reduction approach, may be done with Smith-Petersen or Bikini incision. ${ }^{[1,2,6,8,0]}$ Various successful results have been reported about open reduction treatment with anterior and medial approaches..$^{[2,5,11,12]}$ However, sufficient comparative evidence is not available about the superiorities of open reduction with AOR or MOR approach to each other or which approach should be preferred.
Only a small number of studies are available which compare the clinical and radiologic results of both approaches, the ratio of AVN development and the need of revision surgery. ${ }^{[11,12]}$

In this study, we used a posteromedial approach in the MOR group and bikini incision in the AOR group. Two patients had histories of unsuccessful treatment with previous conservative and closed reduction attempts. On the other hand, the follow-up period was longer in our study as compared to the two studies which compare MOR and AOR and to the best of our knowledge; this is the first study which compares the results of both open reduction approaches with regard to objective radiologic evaluation criteria. However there were a higher number of initial dislocations in the AOR group compared to the MOR group according to Tönnis staging (Table II). This condition results from our preference for medial approach in relatively earlier DDH cases and anterior approach in higher stage dislocations. These results may have affected the results of our study.

Outcomes of DDH treatment may be followed up with many radiologic parameters besides clinical and radiologic evaluation criteria. Modified McKay clinical criteria and Severin radiological criteria are frequently used. Both $\mathrm{AI}$ and $\mathrm{CE}$ angle are the main radiological angles used for follow-up. ${ }^{[21,24,30]}$ Successful clinical results have been reported with a ratio of $92.3-100 \%$ and successful radiologic results have been reported with a $84.6-98 \%$ ratio using the anterior approach. ${ }^{[8,12,13]}$ Successful (excellent-good) clinical outcomes were reported with a ratio of $83-98 \%$ and successful radiologic outcomes were reported with a ratio of $77-91 \%$ with medial approach. ${ }^{[9,13-17]}$ In a study comparing the results of AOR and MOR, Bulut et al. ${ }^{[12]}$ reported that the vast majority $(72.3 \%)$ of cases in MOR group which were followed up for at least 24 
TABLE II

Comparison of clinical, radiological and other outcomes between the groups

\begin{tabular}{|c|c|c|c|c|c|}
\hline \multirow[t]{2}{*}{ Parameters } & \multicolumn{2}{|c|}{ Group MOR (n=21) } & \multicolumn{2}{|c|}{ Group AOR (n=22) } & \multirow[b]{2}{*}{$\mathrm{p}^{\star \star *}$} \\
\hline & $\mathrm{n}$ & $\%$ & $\mathrm{n}$ & $\%$ & \\
\hline Gender & & & & & 0.420 \\
\hline Male & 6 & 28.6 & 4 & 18.2 & \\
\hline Female & 15 & 71.4 & 18 & 81.8 & \\
\hline Laterality & & & & & 0.864 \\
\hline Right & 9 & 42.9 & 10 & 45.5 & \\
\hline Left & 12 & 57.1 & 12 & 54.5 & \\
\hline Prior failed treatment & & & & & 0.973 \\
\hline Yes & 1 & 4.8 & 1 & 4.5 & \\
\hline No & 20 & 95.2 & 21 & 95.5 & \\
\hline Tönnis type & & & & & 0.05 \\
\hline Type 2 & 16 & 76.2 & 7 & 31.8 & \\
\hline Type 3 & 5 & 23.8 & 11 & 50 & \\
\hline Type 4 & 0 & 0 & 4 & 18.2 & \\
\hline Clinical outcomes* & & & & & 0.229 \\
\hline Successful & 17 & 80.9 & 18 & 81.8 & \\
\hline Unsuccessful & 4 & 19.1 & 4 & 18.2 & \\
\hline Radiological outcomes ${ }^{* *}$ & & & & & 0.661 \\
\hline Satisfactory & 16 & 76.2 & 17 & 77.3 & \\
\hline Unsatisfactory & 5 & 23.8 & 5 & 22.7 & \\
\hline Revision surgery & & & & & 0.170 \\
\hline Yes & 3 & 14.3 & 4 & 18.1 & \\
\hline No & 18 & 85.7 & 18 & 81.8 & \\
\hline Avascular necrosis & & & & & 0.933 \\
\hline Yes & 5 & 23.8 & 5 & 22.7 & \\
\hline No & 16 & 76.2 & 17 & 77.3 & \\
\hline
\end{tabular}

months were Tönnis type 3 , successful clinical results were $93.6 \%$, successful radiologic results were $91.5 \%$. In AOR group, all cases were reported to be Tönnis type 4 , the ratio of clinically successful results was $92.3 \%$ and the ratio of radiologically successful results were $84.6 \%$. The authors reported that preoperative AI angles were significantly higher in AOR group however there was a significant improvement in AI angles in both groups.

In our study, all cases in MOR group which were followed up for at least 48 months were Tönnis type 2 and 3, the ratio of clinically successful results was $80.9 \%$ and radiologically successful results were $76.2 \%$. In AOR group, most of the cases (68.2\%) were Tönnis type 3 and 4 . The ratio of clinically successful results was $81.8 \%$ and radiologically successful results were $77.3 \%$. The improvement in AI angle was better in AOR group and the difference was statistically significant (Table I). The improvement of AI angle is similar with that shown in the literature in our study.
However, there were higher initial dislocations in AOR group compared to MOR group according to Tönnis staging in our study (Table II). This condition may have affected our results. We revised the modified Mc-Kay criteria which is frequently used in literature for clinical assessment and described the results as successful and unsuccessful. On the other hand, we evaluated our radiologic results with a more objective system. ${ }^{[2]}$ Radiologic criteria defined by Severin ${ }^{[34]}$ is still the most commonly used assessment system in literature. However it yields encouraging results, has limited objectivity, includes subjective concepts and has low reliability. ${ }^{[2]}$ The radiographic assessment system developed by Ömeroğlu et al. ${ }^{[22]}$ is reported to have sufficient observer reliability and yield more objective results. ${ }^{[22,24]}$ The patients who were five years old and above were included in the study due to these criteria. We consider our results to be more objective due to the criteria we used and the differences with the literature may have resulted from this. 
One of the most threatening complications of DHD is AVN. The need for revision surgery is another important problem. The ratio of AVN has been reported to be between $10-45 \%$ and the need of revision surgery is reported between $0-57 \%$ in medial approach. ${ }^{[9-12,15-17]}$ These ratios are $0-36 \%$ and $0-57 \%$, respectively in the anterior approach. ${ }^{[8,11-14,35]} \mathrm{In}$ a study comparing medial and anterior approaches, Hoellwarth et al. ${ }^{[1]}$ reported that the groups were similar in regards to gender, side and duration of follow-up in patients who were followed up for at least two years. They reported AVN ratio as $22 \%$ and need for further surgery as $21 \%$ in MOR group. These ratios were reported as $28 \%$ and $37 \%$, respectively in AOR group. They reported that there was not a difference between groups with regard to AVN ratio and need for revision surgery. The authors also reported that they could not determine an AVN-related factor however previous unsuccessful closed reductions increased revision surgery risk. In our study, the ratio of AVN was $23.8 \%$ and the need for revision surgery was $14.3 \%$ in MOR group. These ratios were found to be $22.7 \%$ and $18.2 \%$, respectively in AOR group. There was not a statistically significant difference between groups with regard to AVN and the need for revision surgery (Table II). We may state that our results were consistent with those available in the literature. However we did not make a factor analysis for AVN, and there was a history of previous unsuccessful treatment in one case from each group.

There were several limitations for our study. The first is the relatively small number of patients. Secondly computed tomography (CT) examination was not routinely done for control of reduction in each case. We did not prefer to perform routine CT examinations because of the cost of the study and to prevent excessive radiation exposure of the children.

The results of this study indicate that MOR and AOR approaches are similar with regard to clinical and radiologic results, and a significant improvement has been achieved in AI angle using both approaches. There were not any differences between the groups with regard to AVN and need of revision surgery, although preoperative Tönnis stage and the improvement in AI angle were significantly higher in AOR group. In conclusion, both methods are effective in the treatment of DDH cases between the ages of 6-18 months. However, we have concluded that treatment should be planned considering preoperative Tönnis stage, AI angle and the experience/preference of the surgeon.

\section{Declaration of conflicting interests}

The authors declared no conflicts of interest with respect to the authorship and/or publication of this article.

\section{Funding}

The authors received no financial support for the research and/or authorship of this article.

\section{REFERENCES}

1. Herring JA. Developmental dysplasia of the hip. In: Herring JA, editor. Tachdjian's Pediatric Orthopaedics. 5th ed. Philadelphia: Saunders/Elsevier; 2014. p. 504-16.

2. Noordin S, Umer M, Hafeez K, Nawaz H. Developmental dysplasia of the hip. Orthop Rev (Pavia) 2010;2:19.

3. Söyüncü $Y$, Özenci M, Ürgüden M, Akyıldız F, Gür S. Onestage operative treatment of congenital dysplasia of the hip in children of walking age. [Article in Turkish] Eklem Hastalik Cerrahisi 2004;15:200-6.

4. Aksoy MC. Closed reduction in the treatment of developmental dysplasia of the hip. [Article in Turkish] Acta Orthop Traumatol Turc 2007;41:25-30.

5. Cooper AP, Doddabasappa SN, Mulpuri K. Evidence-based management of developmental dysplasia of the hip. Orthop Clin North Am 2014;45:341-54.

6. Kotlarsky P, Haber R, Bialik V, Eidelman M. Developmental dysplasia of the hip: What has changed in the last 20 years? World J Orthop 2015;6:886-901.

7. Xu M, Gao S, Hu Z, Lei G. The greater trochanter located in the acetabulum in a girl with developmental dysplasia of the hip: an unusual complication after redislocation. Eklem Hastalik Cerrahisi 2012;23:49-51.

8. Gem M, Arslan H, Ozkul E, Alemdar C, Azboy I, Demirtaş A. One-stage bilateral open reduction using the anterior iliofemoral approach in developmental dysplasia of the hip. Acta Orthop Belg 2014;80:211-5.

9. Baki C, Sener M, Aydin H, Yildiz M, Saruhan S. Single-stage open reduction through a medial approach and innominate osteotomy in developmental dysplasia of the hip. J Bone Joint Surg Br 2005;87:380-3.

10. Ayanoğlu S. Treatment of developmental dysplasia of the hip between 6-18 months of age. TOTBID Dergisi 2014;13:403-11.

11. Hoellwarth JS, Kim YJ, Millis MB, Kasser JR, Zurakowski $\mathrm{D}$, Matheney TH. Medial versus anterior open reduction for developmental hip dislocation in age-matched patients. J Pediatr Orthop 2015;35:50-6.

12. Bulut M, Gürger M, Belhan O, Batur OC, Celik S, Karakurt L. Management of developmental dysplasia of the hip in less than 24 months old children. Indian J Orthop 2013;47:578-84.

13. Szepesi K, Biró B, Fazekas K, Szücs G. Preliminary results of early open reduction by an anterior approach for congenital dislocation of the hip. J Pediatr Orthop B 1995;4:171-8.

14. Cordier W, Tönnis D, Kalchschmidt K, Storch KJ, Katthagen BD. Long-term results after open reduction of developmental hip dislocation by an anterior approach lateral and medial of the iliopsoas muscle. J Pediatr Orthop B 2005;14:79-87.

15. Tümer Y, Biçimoğlu A, Ağuş H. Surgical treatment of hip dysplasia through the medial approach. [Article in Turkish] Acta Orthop Traumatol Turc 2007;41:31-6. 
16. Erturk C, Altay MA, Yarimpapuc R, Isikan UE. Medial open reduction of developmental dysplasia of the hip using the Weinstein-Ponseti approach. Saudi Med J 2011;32:901-6.

17. Biçimoğlu A, Ağuş H, Omeroğlu H, Tümer Y. Posteromedial limited surgery in developmental dysplasia of the hip. Clin Orthop Relat Res 2008;466:847-55.

18. Szepesi K, Szücs G, Szeverényi C, Csernátony Z. Long-term follow-up of DDH patients who underwent open reduction without a postoperative cast. J Pediatr Orthop B 2013;22:85-90.

19. Biçimoğlu A, Agus H, Omeroğlu H, Tümer Y. Six years of experience with a new surgical algorithm in developmental dysplasia of the hip in children under 18 months of age. J Pediatr Orthop 2003;23:693-8.

20. Zadeh HG, Catterall A, Hashemi-Nejad A, Perry RE. Test of stability as an aid to decide the need for osteotomy in association with open reduction in developmental dysplasia of the hip. J Bone Joint Surg [Br] 2000;82:17-27.

21. Incesu M, Belhan $O$, Karakurt L. Midterm results of Salter and Pemberton pelvic osteotomies for developmental dysplasia of the hip. [Article in Turkish] Eklem Hastalik Cerrahisi 2007;18:7-12.

22. Omeroğlu H, Uçar DH, Tümer Y. A new, objective radiographic classification system for the assessment of treatment results in developmental dysplasia of the hip. J Pediatr Orthop B 2006;15:77-82.

23. Ünlü S, Çatma MF, Bilgetekin YG. Imaging methods in pediatric hip problems. TOTBID Dergisi 2014;13:390-5.

24. Omeroğlu H, Kaya A, Güçlü B. Evidence-based current concepts in the radiological diagnosis and follow-up of developmental dysplasia of the hip. [Article in Turkish] Acta Orthop Traumatol Turc 2007;41:14-8.

25. Salter RB, Kostuik J, Dallas S. Avascular necrosis of the femoral head as a complication of treatment for congenital dislocation of the hip in young children: a clinical and experimental investigation. Can J Surg 1969;12:44-61.

26. Kalamchi A, MacEwen GD. Avascular necrosis following treatment of congenital dislocation of the hip. J Bone Joint
Surg [Am] 1980;62:876-88.

27. Tönnis D. General radiography of the hip joint. In: Congenital Dysplasia and Dislocation of the Hip in Children and Adults, New York: Springer; 1987. p. 100-42.

28. Konya MN, Tuhanioğlu Ü, Aslan A, Yıldırım T, Bursalı A, Şahin V, et al. A comparison of short-term clinical and radiological results of Tönnis and Steel pelvic osteotomies in patients with acetabular dysplasia. [Article in Turkish] Eklem Hastalik Cerrahisi 2013;24:96-101.

29. Yagmurlu MF, Bayhan IA, Tuhanioglu U, Kilinc AS, Karakas ES. Clinical and radiological outcomes are correlated with the age of the child in single-stage surgical treatment of developmental dysplasia of the hip. Acta Orthop Belg 2013;79:159-65.

30. Dogan M, Bozkurt M, Sesen H, Yildirim H. One-stage treatment of congenital severely dislocated hips in older children through various acetabuloplasty techniques: 22 children followed for 1-5 years. Acta Orthop 2005;76:212-9.

31. Atik OŞ, Daldal İ. Salter innominate osteotomy for the treatment of developmental dysplasia of the hip: 37 years of follow-up. [Article in Turkish] Eklem Hastalik Cerrahisi 2015;26:168-70.

32. Ertürk C, Altay MA, Yarimpapuç R, Koruk I, Işikan UE. One-stage treatment of developmental dysplasia of the hip in untreated children from two to five years old. A comparative study. Acta Orthop Belg 2011;77:464-71.

33. Bulut O, Oztürk H, Tezeren G, Bulut S. Arthroscopicassisted surgical treatment for developmental dislocation of the hip. Arthroscopy 2005;21:574-9.

34. Severin E. Contribution to the knowledge of congenital dislocation of the hip joint. Late results of closed reduction and arthrographic studies of recent cases. Acta Chir Scan 1941;84(Suppl 63);1-142.

35. Holman J, Carroll KL, Murray KA, Macleod LM, Roach JW. Long-term follow-up of open reduction surgery for developmental dislocation of the hip. J Pediatr Orthop 2012;32:121-4. 